\title{
Evaluation of biochemical constituents and inhibitory effect of tea clone 100 on colorectal cancer cell line HCT- 116
}

\author{
Fereydoon Bondarian ${ }^{1}$, Asa Ebrahimi ${ }^{2 \star}$, Frouzandeh Mahjoubi ${ }^{3}$, Eslam Majidi \\ Hervan $^{1}$, Reza Azadi Gonbad ${ }^{4}$ \\ ${ }^{1}$ Department of Plant Breeding, ${ }^{2}$ Department of Biotechnology, Science and Research branch, Islamic Azad University, Tehran, \\ ${ }^{3}$ Department of Clinical Genetic, National Institute of Genetic Engineering and Biotechnology, Karaj, ${ }^{4}$ Department of Seed and \\ Plant Improvement, Tea Research Institute (TRI), Guilan 44159-77555, Iran
}

*For correspondence: Email: dr.asaebrahimi@gmail.com; Tel: +989128057492

Sent for review: 15 December 2017

Revised accepted: 9 May 2018

\begin{abstract}
Purpose: To evaluate the total content of polyphenols and the free radical scavenging activity of three different extracts of three types of tea clone 100 (black, green and white), and their anti-proliferative effects on colorectal cancer.

Methods: Five major polyphenols, viz, (+)-catechin, (-)-epicatechin, (-)-epigallocatechin, (-)-epicatechin gallate and (-)-epigallocatechin gallate, were identified using thin layer chromatography (TLC). Catechins were quantified by high performance liquid chromatography (HPLC). Antioxidant activity was measured by DPPH radical scavenging method, while 3-(4, 5-dimethylthiazol-2-yl)-2, 5diphenyltetrazolium bromide (MTT) assay was employed for the determination of cell viability of colon cell line HCT-116 after 24 and $48 \mathrm{~h}$.

Results: The aqueous methanol (70\%) extract of white tea yielded the highest amount of polyphenols (36.67 $\pm 0.54 \mathrm{mg} \mathrm{GAE} / \mathrm{g}$ dry weight). The DPPH radical scavenging activity of white tea was $71.74 \pm$ $0.42 \%$, and it produced high anti-proliferation activity against colorectal cancer cell line HCT-116 (86.06 $\pm 0.54 \%$ ).

Conclusion: White tea extract possesses high DPPH radical scavenging activity, and exerts good antiproliferative effects against colorectal cancer cell line HCT-116, most likely due to its catechin content.
\end{abstract}

Keywords: Camellia sinensis L., Catechin, DPPH radical scavenging, Anti-cancer

\begin{abstract}
This is an Open Access article that uses a funding model which does not charge readers or their institutions for access and distributed under the terms of the Creative Commons Attribution License (http://creativecommons.org/licenses/by/4.0) and the Budapest Open Access Initiative (http://www.budapestopenaccessinitiative.org/read), which permit unrestricted use, distribution, and reproduction in any medium, provided the original work is properly credited.
\end{abstract}

Tropical Journal of Pharmaceutical Research is indexed by Science Citation Index (SciSearch), Scopus, International Pharmaceutical Abstract, Chemical Abstracts, Embase, Index Copernicus, EBSCO, African Index Medicus, JournalSeek, Journal Citation Reports/Science Edition, Directory of Open Access Journals (DOAJ), African Journal Online, Bioline International, Open-J-Gate and Pharmacy Abstracts

\section{INTRODUCTION}

Tea (Camellia sinensis L.), which belongs to the Theaceae, family is the second most widely consumed drink in the world after water, and it is rich in polyphenols [1]. Iranian teas are of immense use to the pharmaceutical, cosmetic, and food industries because their contents of high purity polyphenolic compounds, high antioxidant properties and absence of additives [2]. Generally, tea can be classified into three types: unfermented (green and white teas), 
partially fermented (oolong tea), and completely fermented (black tea) [3]. White tea harvested before the tea plant leaves open fully, is light in colour and made from buds and immature leaves that are covered with fine white hairs, and undergo little or no oxidation before drying [4].

The major catechins present in tea are (-)epigallocatechin, (+)-catechin, (-)epigallocatechin gallate, (-)-epicatechin and (-)epicatechin gallate [5] (Figure 1). Studies have shown that public awareness about the benefits of tea has increased in the recent past [6]. Majority of the beneficial effects of tea are related to the primary polyphenolic constituents of tea and its strong antioxidant potential [7]. It has beneficial effects against cancers [8], cardiovascular diseases [9], and diabetes [10]. In general, polyphenols are classified into four classes: phenolic acids, flavonoids, lignans, and stilbenes [11]. In recent years, lots of epidemiological studies were focused on bioactive phytochemicals such as phenolic compounds because of their beneficial effects on human health [12]. The antioxidant activities of phenolic compounds are due to their redox features, which allow them to play role as reductive agents, singlet-oxygen quenchers, and metallic-ion chelators [13].

Cancers are a complex group of diseases caused by environmental and genetic factors [14]. Cancers are rarely the result of a single exposure or factor: a combination of exposures and genetic factors lead to multiple types of genetic damage and modification of multiple genetic pathways [15]. Colorectal cancer (CRC) is one of the major causes of cancer mortality, and the second and third major cause of cancer incidence among females and males, respectively. Alarmingly, increasing numbers of reported cases of colon cancer in recent years have made this type of cancer one of the major health concerns [16,17]. The American Cancer Society reported 96,830 cases of colon and 40,000 cases of rectal cancers in $2014[16,17]$.

The MTT assay is an indirect colorimetric assay for determining cell viability. It is highly recommended for studying the cytotoxic effects of xenobiotics and herbal extracts, and for analysing cell activity [18].

The aim of this research was to evaluate the total content of polyphenolic compounds, and the antioxidant activities of three types of tea clone 100 (white, green and black) extracted with different solvent extraction methods. The second goal was to assess the usefulness of the MTT assay in analysing white tea extract, and the effect of different concentrations of tea extracts on anti-proliferation in the colorectal cancer cell line, HCT-116.
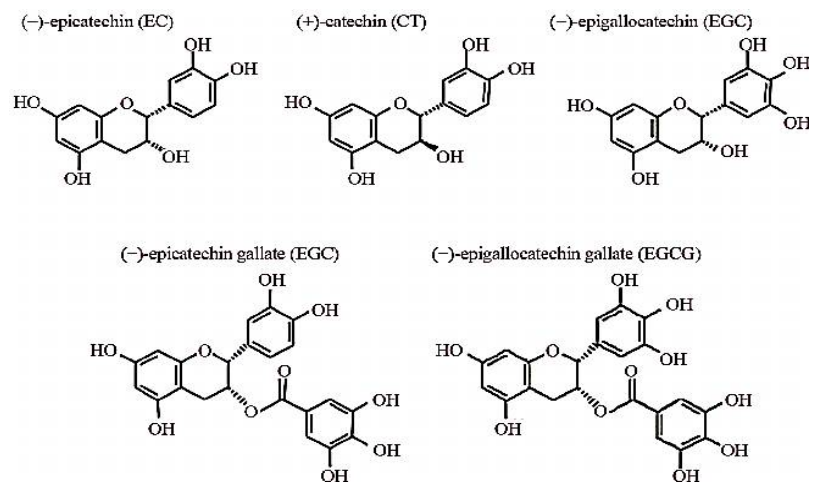

Figure 1: Major polyphenol structures in three types of tea (white, green and black)

\section{EXPERIMENTAL}

\section{Plant material}

Leaves of white, green and black tea clone 100, (C. sinensis (L.) O. kuntze), belonging to the theaceae family were used in this research. The samples were collected during the growing season, spring 2016, by Tea Research Institute of Iran (GPS location of $37^{\circ} 14^{\prime} 30^{\prime \prime} \mathrm{N}$ latitude and $52^{\circ} 3^{\prime} 2^{\prime \prime}$ E longitude) [19].

\section{Extraction method}

The method described by International Organization for Standardization (ISO) 14502-1 [20] was used for extraction, with some modifications. Three solvents were applied for extraction.

\section{Methanol (70 \%) extraction}

In this method, $0.5 \pm 0.001 \mathrm{~g}$ of each tea leaf sample (white, green and black, from clone 100 Iran) was ground in liquid nitrogen, and put into extraction tubes. Then, $10 \mathrm{~mL}$ of $70 \%$ methanol was added at $70{ }^{\circ} \mathrm{C}$, and the mixture was heated at $70{ }^{\circ} \mathrm{C}$ on bain-marie for $10 \mathrm{~min}$. Then, the extract tubes were sonicated for $5-7 \mathrm{~min}$, and heated again at $70{ }^{\circ} \mathrm{C}$ for $10 \mathrm{~min}$. After cooling at room temperature, the extract was centrifuged at $3500 \mathrm{rpm}$ for $10 \mathrm{~min}$, and the supernatant was decanted into graduated tubes. One $\mathrm{ml}$ of extract was diluted to $10 \mathrm{~mL}$ with distilled water for use in the different chemical analysis.

\section{Aqueous extraction}

In this method, $10 \mathrm{~mL}$ of boiling water was added to $0.5 \pm 0.001 \mathrm{~g}$ of each tea leaf sample in 
extraction tubes, and the extraction followed the methanol method as described above.

\section{Aqueous - methanol (70 \%) extraction}

In this method, $5 \mathrm{~mL}$ of distilled water at $100{ }^{\circ} \mathrm{C}$ and $5 \mathrm{~mL}$ of $70 \%$ methanol at $70{ }^{\circ} \mathrm{C}$ were added to $0.5 \pm 0.001 \mathrm{~g}$ of each tea leaf sample in an extraction tube, and the extraction steps were as described for the methanol method.

\section{Determination of total polyphenolic content}

The total polyphenolic content (TPC) was measured spectrophotometrically using the FolinCiocalteu reagent, with gallic acid (99\% purity, Sigma, Germany) as standard, as described by the ISO 14502-1. Each diluted tea extract (1 mL) was taken (in triplicates) in separate tubes containing $5 \mathrm{~mL}$ of a 1:10 dilution of FolinCiocalteu reagent (Merck chemicals, Germany) in water. Then, $4 \mathrm{~mL}$ of an anhydrous sodium carbonate solution $(7.5 \% \mathrm{w} / \mathrm{v}, 95 \%$ purity, Tebazma Co., Iran) was added, and the tube contents were vortexed for $5 \mathrm{~min}$, and then allowed to stand at room temperature for $1 \mathrm{~h}$. In some references, sodium carbonate was omitted from the tubes. In this research, both methods were compared (to determine the difference between them). The absorbance was measured at $765 \mathrm{~nm}$ against distilled water. The concentrations of polyphenols in the samples were derived from a gallic acid standard curve (Pearson correlation coefficient $r^{2}=0.9877$ ), and the TPC was expressed as $\mathrm{mg}$ gallic acid equivalents (GAE)/g dry weight.

\section{TLC analysis}

For TLC analysis, silica gel plates (layer thickness $0.20 \mathrm{~mm}$; Sigma), were put in the chromatographic chamber $(12 \times 10 \times 8 \mathrm{~cm}$; Sigma) containing the mobile phase solvent system: chloroform, acetic acid and methanol (all Merck Chemicals, Germany) at volume ratio of $80: 16: 4$. After developing the chromatogram, the spots were located on the plate under the UV lamp at $254 \mathrm{~nm}$. The spots were identified by comparison of $R_{f}$ values.

\section{HPLC analysis}

The HPLC system consisted of Shimadzu with a fixed wavelength UV-VIS detector (Model LC10AD VP), and a Rheodyne sample injector with a $20 \mu \mathrm{L}$ sample loop. The chromatography column was C18 (300 mm x $3.9 \mathrm{~mm}$ ID $\times 5 \mu \mathrm{m})$. The mobile phase flow rate was $1 \mathrm{ml} / \mathrm{min}$, and detection was carried out by measurement of UV absorbance at $280 \mathrm{~nm}$. The mobile phase was composed of water, acetonitrile, methanol, ethyl acetate and glacial acetic acid (89:6:3:1:1 v/v/v/v/v) (Merck, Germany). A Star v6.3 software (Varian) was used for the operation of the detector and data processing static phase [22]. Catechin concentration of each samples was determined using Eq 1 [23].

$$
C(u)=A(u) X C(s t) / A(s t)
$$

where $C(u)$ is the concentration of unknown sample, $A(u)$ is the peak area of the unknown sample, $C$ (st) is the concentration of the standard, and $A(s t)$ is the area peak of standard.

\section{Determination of DPPH radical scavenging activity}

The DPPH radical scavenging activities of the extracts were assayed using the modified method of Blois [21]. A volume of $1 \mathrm{~mL}$ of each extract was mixed with $5 \mathrm{~mL}$ of $500 \mu \mathrm{M}$ DPPH solution in absolute ethanol, and $2.5 \mathrm{~mL}$ of $0.1 \mathrm{M}$ Tris- $\mathrm{HCl}$ buffer, $\mathrm{pH}$ 7.4. The mixture was kept for $30 \mathrm{~min}$ in darkness at room temperature. Then the absorbance was read at $517 \mathrm{~nm}$ in a spectrophotometer. The free radical scavenging activity of polyphenols in the samples was derived from a standard curve of ascorbic acid (Sigma, Germany). Radical scavenging was calculated in terms of \% inhibition as in Eq 2.

Inhibition $(\%)=\left\{\left(A_{0}-A_{1}\right) / A_{0}\right\} 100$

where $A_{0}$ is the absorbance of the control, and $A_{1}$ is the absorbance of the samples.

\section{Cell culture}

Human colorectal carcinoma cells (HCT-116) were used in MTT assay to determine cell viability. HCT-116 (ATCC_ HTB-38TM) cells were cultured and grown in DMEM high glucose (Bio idea Co. Iran). The cells were supplemented with $10 \%$ foetal bovine serum and $0.5 \%$ pen-strep \{penicillin $(10 \mathrm{U} / \mathrm{ml})$, and streptomycin $(10$ $\mu \mathrm{g} / \mathrm{ml})\}$ in a humidified incubator with $5 \% \mathrm{CO}_{2}$ (Figure 2).

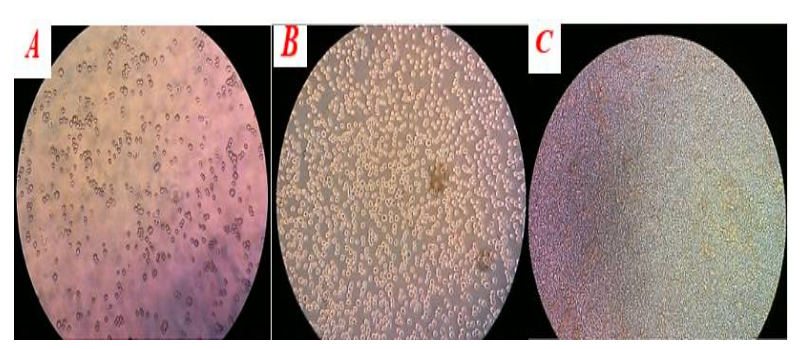

Figure 2: (A) First day culture of cell line HCT-116, (B) second day of cell culture, $(C)$ third day of culture

Trop J Pharm Res, June 2018; 17(6): 1035 


\section{Cell count and viability assay}

The cell count was determined by counting the cells in haemocytometer. About $0.2 \mathrm{~mL}$ of the cell suspension was diluted in $0.2 \mathrm{~mL}$ of Trypan blue $(0.1 \%)$, and transferred into the haemocytometer immediately. The viable cells (non-viable cells are stained blue, and viable cells remain unstained) were counted in each corner of the chambers. Cells lying on the top and to the left were eliminated. The total number of cells, which had been seeded at a concentration of $10^{4}$ cells/well, in a 24-well plate was calculated as in Eq 3.

$C l=T b \times(T / 4) \times 10^{4}$,

where $\mathrm{Cl}=$ initial cell concentration, $T=$ total viable cell count of 4 squares, $T b=$ correction for the trypan blue dilution, $T / 4=$ correction to give mean cells/corner square, and $10^{4}=$ conversion factor for counting chamber.

\section{In vitro anti-proliferative effects of white tea extract (WTE)}

The inhibitory effect of WTE on the proliferation of the colorectal carcinoma cell line, HCT-116, was determined by using the MTT assay [24]. In brief, cells were seeded in 96-well plates at 5000 cells/well, and allowed to attach overnight. Then the media was changed, and the cells were treated with various concentrations of the extract $(0-1000 \mu \mathrm{g} / \mathrm{mL})$ incubated for $24 \mathrm{~h}$ and $48 \mathrm{~h}$. Thereafter, $10 \mathrm{~mL}$ of MTT solution $(100 \mathrm{mM}$ of MTT bromide in RPMI-1640) was added to each well plate, and incubated for $4 \mathrm{~h}$ at $37^{\circ} \mathrm{C}$. The supernatant was aspirated, and the MTTformazan crystals formed by metabolically viable cells were dissolved in $50 \mathrm{ml}$ of dimethyl sulphoxide (DMSO). Eventually, the absorbance of each well-plates was monitored in a microplate reader at a wavelength of $580 \mathrm{~nm}$. Growth inhibition of the cells was calculated using Eq 4 [25]:

Inhibition $\left.(\%)=\left\{\left(A_{b}-A_{s}\right) / A_{b}\right)\right\} 100$,

Where $A b$ and As are the absorbance of blank and test samples, respectively.

\section{Determination of half-maximal inhibitory concentration $\left(\mathrm{IC}_{50}\right)$}

The extract concentration that reduced the viability of cells by $50 \%\left(\mathrm{IC}_{50}\right)$ was determined by plotting triplicate data points over a concentration range. The $I_{50}$ results was indicated as regression analysis using GraphPad PRISM. Calculation of confidence limits and significance testing were made at the level of $p=$ 0.05 .

\section{Statistical analysis}

Data are presented as mean $\pm S D$, and all measurements and analysis were carried out in triplicate $(\mathrm{n}=3)$. Excel 2013 and SPSS V.22.0 statistical packages were used for the statistical and graphical evaluations. Statistical analysis was performed by one-way analysis of variance (ANOVA) with Duncan multiple comparisons, and Student's $t$-test. All $p$ values $<0.05$ were considered significant.

\section{RESULTS}

\section{Total phenolic content}

There were significant differences between the total phenolic contents (TCPs) of aqueous extracts of black, green, and white tea in presence of sodium carbonate (Table 1). Black tea extract had the lowest content of polyphenols (18.99 $\pm 0.47 \mathrm{mg} \mathrm{GAE} / \mathrm{g} \mathrm{DW})$, while the TPCs of green tea and white extracts were $23.45 \pm 1.03$ and $27.08 \pm 0.59 \mathrm{mg} \mathrm{GAE} / \mathrm{g}$ dry weight, respectively. In this method of extraction, the TPC result for white tea was significantly different from those of green and black tea $(p<0.05$, Table 1). The TPCs of $70 \%$ methanol extracts of white, green, and black tea clone 100 were 13.68 $\pm 0.26,13.12 \pm 0.07$, and $12.45 \pm 0.38 \mathrm{mg} \mathrm{GAE} / \mathrm{g}$ dry weight, respectively.

Similar results were obtained in the presence of sodium carbonate, i.e., black tea extract still had the lowest content of polyphenols (14.65 \pm 0.39 $\mathrm{mg} \mathrm{GAE} / \mathrm{g}$ dry weight), relative to green tea extract (16.85 $\pm 0.5 \mathrm{mg} \mathrm{GAE} / \mathrm{g}$ dry weight), and white tea extract $(21.52 \pm 0.81 \mathrm{mg} \mathrm{GAE} / \mathrm{g}$ dry weight). The third method of TPC estimation in tea extract was significantly more efficient than the first one. In this study, both solvents were used together. The result of TPCs of three types of tea extracted with $70 \%$ methanol and distilled water showed that black tea extract had the lowest amount of polyphenols (16 $\pm 0.21 \mathrm{mg}$ GAE/g DW), when compared with green tea extract (18.64 $\pm 0.46 \mathrm{mg} \mathrm{GAE} / \mathrm{g}$ dry weight), and white tea extract $(23.08 \pm 0.76 \mathrm{mg} \mathrm{GAE} / \mathrm{g}$ dry weight).

The same pattern of TPC was achieved when sodium carbonate was added. The black tea extract still had the lowest TPC $(21.68 \pm 0.59 \mathrm{mg}$ GAE/g dry weight), followed by green tea extract (27.54 $\pm 0.84 \mathrm{mg} \mathrm{GAE} / \mathrm{g}$ dry weight), and white tea extract (36.67 $\pm 0.54 \mathrm{mg} \mathrm{GAE} / \mathrm{g}$ dry weight) (Table1). In this method, the TPC of white tea 
was significantly higher than those of black tea and green tea $(p<0.01)$.

Table 1: Total phenolic contents of different tea extracts clone 100 as a function of method used (GAE/g dry weight)

\begin{tabular}{|c|c|c|}
\hline Extract & $\begin{array}{c}\text { TPC via } \\
\text { Folin- } \\
\text { Ciocalteu's }\end{array}$ & $\begin{array}{c}\text { TPC via } \\
\text { Folin- } \\
\text { Ciocalteu's } \\
\text { plus sodium } \\
\text { carbonate }\end{array}$ \\
\hline Aqueous/white tea & $17.91 \pm 0.33^{*}$ & $27.08 \pm 0.59^{*}$ \\
\hline Aqueous/green tea & $15.94 \pm 021$ & $23.45 \pm 1.03$ \\
\hline Aqueous/black tea & $12.84 \pm 0.84$ & $18.99 \pm 0.47$ \\
\hline $\begin{array}{l}\text { Methanol (70 } \\
\%) / \text { white tea }\end{array}$ & $13.68 \pm 0.26$ & $21.52 \pm 0.81$ \\
\hline $\begin{array}{l}\text { Methanol (70 } \\
\%) / g r e e n ~ t e a\end{array}$ & $13.12 \pm 0.07$ & $16.85 \pm 0.50$ \\
\hline $\begin{array}{l}\text { Methanol (70 \%) } \\
\text { /black tea }\end{array}$ & $12.45 \pm 0.38$ & $14.65 \pm 0.39$ \\
\hline $\begin{array}{l}\text { Aqueous - methanol } \\
(70 \%) / \text { white tea }\end{array}$ & $23.08 \pm 0.76^{\star *}$ & $36.67 \pm 0.54^{* *}$ \\
\hline $\begin{array}{l}\text { Aqueous - methanol } \\
(70 \%) / g r e e n \text { tea }\end{array}$ & $18.64 \pm 0.46^{\star}$ & $27.54 \pm 0.84^{\star}$ \\
\hline $\begin{array}{l}\text { Aqueous - methanol } \\
(70 \%) / \text { black tea }\end{array}$ & $16 \pm 0.21$ & $21.68 \pm 0.59$ \\
\hline
\end{tabular}

Data are expressed as mean \pm SD $(n=3)$. Values with different superscript letters in a column are statistically different $\left({ }^{* *} p<0.01 ;{ }^{*} p<0.05\right)$

\section{Gallic acid in extracts}

In TLC assay, gallic acid was detected in the three types of tea extracts. From the results, the highest differences in $R_{f}$ values appeared in those teas extracted with distilled water $(0.211$, 0.213 and 0.214; Table 2). Therefore, distilled water extraction method was the best method for the separation of gallic acid. The $R_{f}$ value obtained for gallic acid in this study was comparable to the $\mathrm{R}_{\mathrm{f}}$ obtained by Amarowicz [23] (Figure 3).

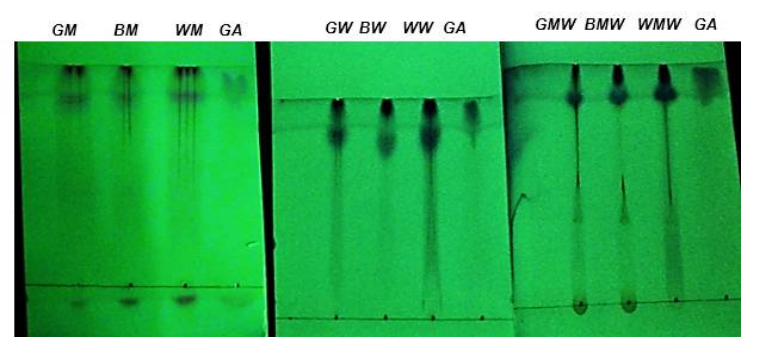

Figure 3: TLC profile for detection of gallic acid in three types of extracts. GM: green tea extracted with methanol; BM: black tea extracted with methanol; WM: white tea extracted with methanol; GMW: green tea extracted with the mixture of methanol + distilled water; BMW: black tea extracted with the mixture of methanol and distilled water; WMW: white tea extracted with the mixture of methanol and distilled water; GW: green tea extracted with distilled water; BW: black tea extracted with distilled water; WW: white tea extracted with distilled water; GA: gallic acid

Table 2: Gallic acid $\mathrm{R}_{\mathrm{f}}$ in different teas

\begin{tabular}{|c|c|}
\hline Extraction type / tea sample & $\mathbf{R}_{\mathrm{f}}$ for gallic acid \\
\hline Methanol (70 \%) / black tea & $0.221 \pm 0.022$ \\
\hline Methanol (70 \%) / green tea & $0.227 \pm 0.031$ \\
\hline Methanol (70 \%) / white tea & $0.220 \pm 0.011$ \\
\hline Aqueous / black tea & $0.213 \pm 0.012^{*}$ \\
\hline Aqueous / green tea & $0.214 \pm 0.017^{*}$ \\
\hline Aqueous / white tea & $0.211 \pm 0.031$ * \\
\hline $\begin{array}{l}\text { Aqueous - methanol (70\%) / } \\
\text { black tea }\end{array}$ & $0.208 \pm 0.029$ \\
\hline $\begin{array}{l}\text { Aqueous - methanol (70\%) / } \\
\text { green tea }\end{array}$ & $0.201 \pm 0.024$ \\
\hline $\begin{array}{l}\text { Aqueous - methanol }(70 \%) \text { / } \\
\text { white tea }\end{array}$ & $0.203 \pm 0.028$ \\
\hline Gallic acid standard & $0.216 \pm 0.011$ \\
\hline $\begin{array}{l}\text { Results are expressed as } n \\
{ }^{*} \text { statistically significant }(p<0.0\end{array}$ & $\pm S D \quad(n=3)$ \\
\hline
\end{tabular}

Five types of compounds C, EGC, ECG, EGCG, EGCG, and gallic acid were identified. Differences between their retention times, and absorption spectra were compared with standard references. Related to HPLC chromatograms, content of polyphenols was remarkably different in white, green, and black tea extracts. In white tea the concentrations of EGCG and other polyphenolic compounds were higher in comparison with green, and black teas profiles. In white tea, EGCG and other polyphenols were present in high amount, relative to green and black tea. HPLC chromatograms for green and black tea extracts showed that different fermentation times directly affected the amount and structure of polyphenols in the extracts [Table 3, Table 4 and Table 5].

\section{DPPH radical scavenging activity}

The results of this study showed that the extraction of white tea extracted using the three different solvent methods effectively reduced its DPPH radical scavenging activity, relative to their high catechin contents. In addition, extraction with aqueous - methanol $(70 \%)$ and water resulted in higher yield of catechins, when compared with $70 \%$ methanol (Table 6). This could be due to the presence of high levels of epigallocatechin gallate (EGCG), which is one of major polyphenols in white tea [27]. The $\mathrm{IC}_{50}$ values of the various tea extracts were expressed in $\mu \mathrm{g} / \mathrm{ml}$. Ascorbic acid was used as standard. 
Table 3: Contents of individual tea catechins in black tea samples ( $\mathrm{mg} / \mathrm{g}$ dry weight)

\begin{tabular}{lcccccc}
\hline $\begin{array}{l}\text { Extraction } \\
\text { method }\end{array}$ & GA & EGC & C & EC & EGCG & ECG \\
\hline $\begin{array}{l}\text { Methanol } \\
\begin{array}{l}70 \%) \\
\text { Aqueous }\end{array}\end{array}$ & $1.38^{\mathrm{c}}$ & $1.22^{\mathrm{a}}$ & $0.33^{\mathrm{c}}$ & $0.64^{\mathrm{D}}$ & $2.91^{\mathrm{c}}$ & $0.53^{\mathrm{c}}$ \\
$\begin{array}{l}\text { Aqueous - } \\
\text { methanol }(70 \%)\end{array}$ & $1.41^{\mathrm{bc}}$ & $1.43^{\mathrm{bc}}$ & $0.41^{\mathrm{ab}}$ & $0.69^{\mathrm{D}}$ & $3.07^{\mathrm{D}}$ & $0.58^{\mathrm{bc}}$ \\
\hline
\end{tabular}

Data are expressed as Duncan ${ }^{\text {a.b }}$ variance comparison $(n=3) .{ }^{*}$ Gallic acid $(G A),(-)$-epigallocatechin (EGC), (+)catechin (C), (-)-epigallocatechin gallate (EGCG), (-)-epicatechin (EC) and (-)-epicatechin gallate (ECG)

Table 4: Contents of individual tea catechins in green tea samples ( $\mathrm{mg} / \mathrm{g}$ dry weight)

\begin{tabular}{|c|c|c|c|c|c|c|}
\hline $\begin{array}{l}\text { Extraction } \\
\text { method }\end{array}$ & GA & EGC & C & EC & EGCG & ECG \\
\hline $\begin{array}{l}\text { Methanol } \\
(70 \%)\end{array}$ & $2.27^{d}$ & $2.20^{d}$ & $0.44^{\mathrm{d}}$ & $1.19^{c}$ & $4.15^{\mathrm{cd}}$ & $0.63^{\mathrm{DC}}$ \\
\hline Aqueous & $2.33^{\mathrm{DC}}$ & $2.78^{\mathrm{DC}}$ & $0.53^{\mathrm{DC}}$ & $1.31^{\mathrm{ab}}$ & $4.21^{\mathrm{D}}$ & $0.69^{\mathrm{D}}$ \\
\hline $\begin{array}{l}\text { Aqueous - } \\
\text { methanol (70 \%) }\end{array}$ & $2.47^{a}$ & $2.93^{a}$ & $0.60^{a}$ & $1.38^{a}$ & $4.38^{a}$ & $0.72^{\mathrm{a}}$ \\
\hline
\end{tabular}

Table 5: Contents individual tea catechins in white tea samples ( $\mathrm{mg} / 100 \mathrm{~g}$ dry weight)

\begin{tabular}{|c|c|c|c|c|c|c|}
\hline $\begin{array}{l}\text { Extraction } \\
\text { method }\end{array}$ & GA & EGC & C & EC & EGCG & ECG \\
\hline $\begin{array}{l}\text { Methanol } \\
(70 \%)\end{array}$ & $2.44^{\mathrm{d}}$ & $5.63^{d}$ & $0.68^{\mathrm{DC}}$ & $1.62^{d}$ & $6.91^{\mathrm{DC}}$ & $1.08^{C}$ \\
\hline Aqueous & $2.56^{\mathrm{DC}}$ & $6.02^{\mathrm{DC}}$ & $0.74^{\mathrm{D}}$ & $1.71^{\mathrm{bc}}$ & $6.95^{\mathrm{bc}}$ & $1.14^{\mathrm{ab}}$ \\
\hline $\begin{array}{l}\text { Aqueous - } \\
\text { methanol (70 \%) }\end{array}$ & $2.66^{a}$ & $6.14^{a}$ & $0.90^{\mathrm{a}}$ & $1.83^{a}$ & $7.03^{a}$ & $1.19^{\mathrm{a}}$ \\
\hline
\end{tabular}

Table 6: DPPH scavenging activities of three type of tea clone 100 extracted with different solvents

\begin{tabular}{|c|c|}
\hline $\begin{array}{l}\text { Extraction solvent/tea } \\
\text { sample }\end{array}$ & $\begin{array}{l}\text { DPPH radical } \\
\text { scavenging activity } \\
\left(\mathrm{IC}_{50}\right),(\mu \mathrm{g} / \mathrm{ml})\end{array}$ \\
\hline Aqueous / white tea & $66.61 \pm 0.27^{\star \star}$ \\
\hline Aqueous / green tea & $30.79 \pm 0.42$ \\
\hline Aqueous / black tea & $24.73 \pm 0.53$ \\
\hline $\begin{array}{l}\text { Aqueous + methanol }(70 \%) / \\
\text { white tea }\end{array}$ & $71.74 \pm 0.42^{\star *}$ \\
\hline $\begin{array}{l}\text { Aqueous + methanol }(70 \%) \text { / } \\
\text { green tea }\end{array}$ & $52.61 \pm 0.63^{*}$ \\
\hline $\begin{array}{l}\text { Aqueous + methanol }(70 \%) \text { / } \\
\text { black tea }\end{array}$ & $46.98 \pm 0.24^{*}$ \\
\hline Methanol (70 \%) / white tea & $47.90 \pm 0.31^{*}$ \\
\hline Methanol (70 \%) / green tea & $25.11 \pm 0.42$ \\
\hline Methanol (70 \%) / black tea & $31.92 \pm 0.14$ \\
\hline Ascorbic acid & $15.06 \pm 0.14$ \\
\hline \multicolumn{2}{|c|}{$\begin{array}{l}\text { Data are expressed as mean } \pm \mathrm{SD}(\mathrm{n}=3) \text {. Values with } \\
\text { different superscript letters in a column are statistically } \\
\text { different }\left({ }^{\star \star} p<0.01 ;{ }^{*} p<0.05\right)\end{array}$} \\
\hline
\end{tabular}

HCT-116 cells were treated with different concentrations of white tea extracts $(0-1000$ $\mu \mathrm{g} / \mathrm{mL}$ ) for $24 \mathrm{~h}$ and $48 \mathrm{~h}$ (Figure 4). Aqueous extraction was the best extraction method that yielded the highest polyphenol contents, and highest radical scavenging activity. Aqueous extract of white tea clone 100 at a concentration of $1000 \mu \mathrm{g} / \mathrm{mL}$, had strong anti-proliferative activity on HCT-116 cells in $24 \mathrm{~h}\left(\mathrm{IC}_{50}=75.87 \pm\right.$ $0.061 \mu \mathrm{g} / \mathrm{mL}$ ) (Figure 5). The result showed that in $48 \mathrm{~h}$, the same concentration of tea extract had $I_{50}$ of $86.06 \pm 0.023 \mu \mathrm{g} / \mathrm{mL}$ (Figure 6). Within $24 \mathrm{~h}$ and $48 \mathrm{~h}$, the anti-proliferative activity of the white tea extract was concentrationdependent.

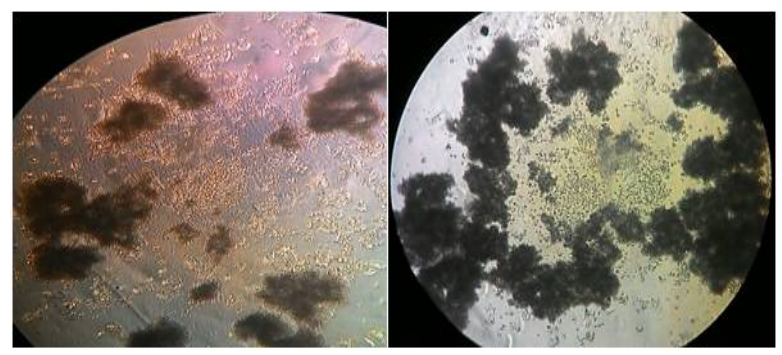

Figure 4: Anti-proliferative effect of white tea extract against HCT- 116 cells within $24 \mathrm{~h}$ and $48 \mathrm{~h}$

Trop J Pharm Res, June 2018; 17(6): 1038 


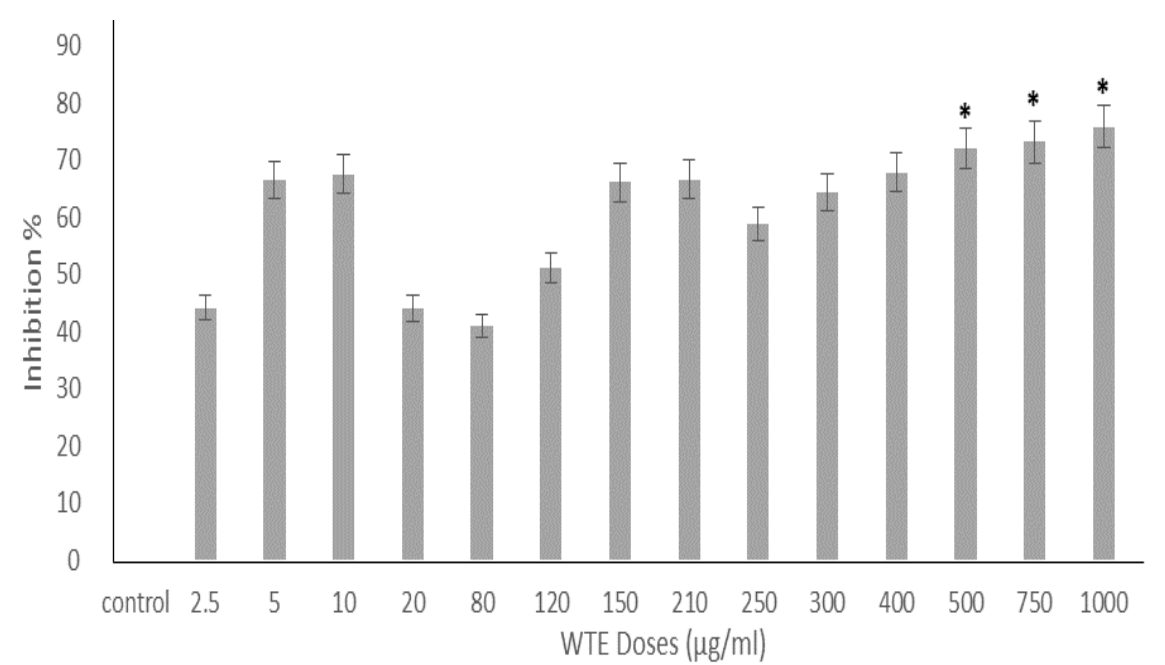

Figure 5: Inhibitory effect of aqueous extract of white tea on the growth of HCT-116 line in $24 \mathrm{~h}$

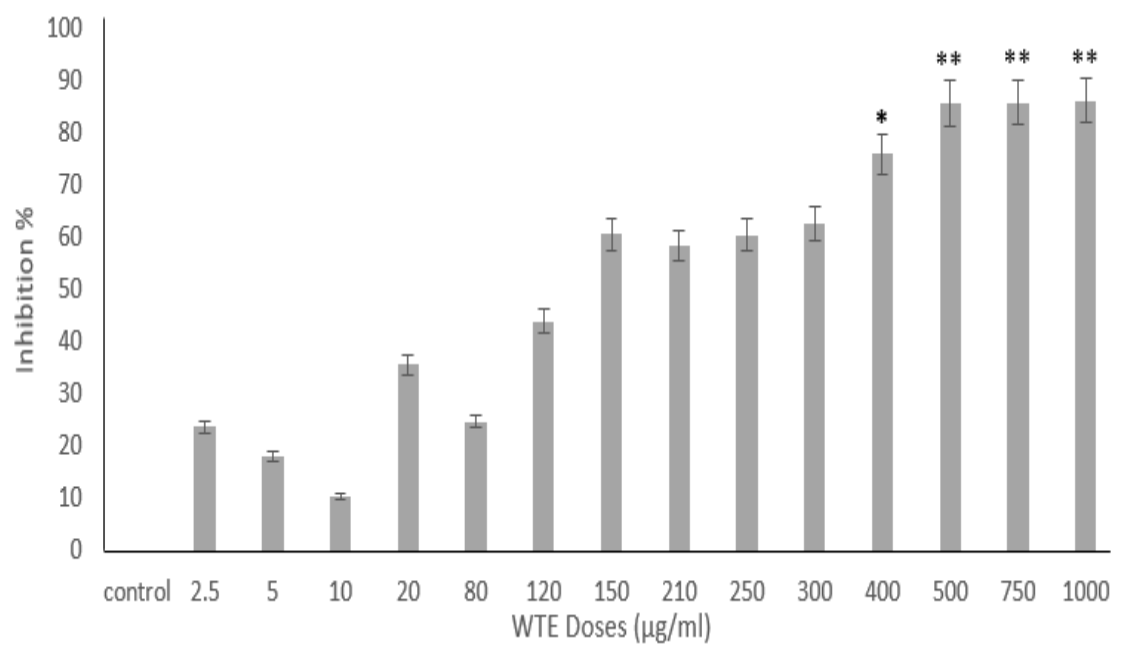

Figure 6: Inhibitory effect of aqueous extracts of white tea on the growth of HCT-116 line in $48 \mathrm{~h}$

\section{DISCUSSION}

The results for both methods of TPC estimation showed that unfermented tea (white tea) had the highest amount of polyphenols. It has been reported that when tea leaves are fermented for a long time, the flavonoid and phenolic structures may become degraded and unstable [25]. The detection of these compounds is in good agreement with the chemical composition of tea as widely described elsewhere [26]. Minor catechins such as EGC and EC were significantly higher in white and green tea products. It has been suggested that most of polyphenols and flavonoid compounds could be detected in white tea clearly because of lower fermentation used in its processing, as opposed to green and black tea [27]. High temperature related to solvent extraction can degrade polyphenol structures [28]. The best solvent combination for polyphenol extraction was distilled water and methanol $(70 \%)$. Distilled water was more efficient than the other solvents. A study reported that the most efficient mobile phase for separation of catechin (EGCG and ECG) was a mixture of acetonitrile, methanol and acetic acid $[29,30]$.

The present results showed that regardless of the type of extraction method, white and green tea extracts had more scavenging activity than black tea, due to their higher content of catechin, which is a known antioxidant compound. Tea TPC has been linked to DPPH radical capacity [30]. Indeed, catechin levels influence the antioxidant capacity of tea [29]. Phenolic structures in different tea extracts inhibit the radical scavenging activity of tea. The polyphenols usually decrease the reaction of oxygen and nitrogen species. Several studies have proposed the inhibitory effect of tea against carcinogenesis of lung, skin, oesophagus, liver, and stomach $[31,32]$. These are in agreement with the results of the present study.

\section{CONCLUSION}

This study has demonstrated that white and 
green teas have more phenolic compounds (catechin and flavonoids) than black tea. Higher amounts of phenolic content were obtained by inclusion of sodium carbonate in the FolinCiocalteu assay. Aqueous methanol (70\%) extraction method was the best method for extracting polyphenols from all the tea types studied. White tea extracted with this method had higher TPC content and higher DPPH radical scavenging activity than extracts obtained using any of the other methods. In addition, aqueous extract of white tea, at higher doses exhibited high anti-proliferative activity against HCT-116 cells in $48 \mathrm{~h}$. Thus, the extract possesses appreciable anti-carcinogenic properties, due obviously to its high TPC.

\section{DECLARATIONS}

\section{Acknowledgement}

This research was supported by Islamic Azad University (IAU), Science and Research branch in collaboration with Razi Laboratory Complex (RLC).

\section{Conflict of Interest}

No conflict of interest associated with this work.

\section{Contribution of Authors}

The authors declare that this work was done by the authors named in this article and all liabilities pertaining to claims relating to the content of this article will be borne by them.

\section{REFERENCES}

1. Namita $P$, Mukesh R, Vijay KJ. Camellia Sinensis (Green Tea): A Review. Global J. Pharmacol. 2012; 6(2): 52-59.

2. Tea Research Institute Annual Report, The History of Tea in Iran. 2013; 180-188. http://chay.areeo.ac.ir

3. Jingjing $N$, Jingjing $S$, Shuhuai L, Mengge S, Zhengzhu Z. Classification of Five Chinese Tea Categories with Different Fermentation Degrees Using Visible and Nearinfrared Hyperspectral Imaging. Int. J. Food Pro. 2017; 20: 1515-1522.

4. Hilal $Y$, Engelhardt UH. A new myricetinrhamnodiglucoside from Camellia sinensis. Nat. Prod. Res. 2009; 23(17): 1621-1629.

5. Calhau C, Faria A, Keating E, Martel A. Interaction of Polyphenols with The Intestinal and Placental Absorption of Some Nutrients and Other Compounds. Polyphenols in Human Health and Disease. J. Funct Foods. 2014; 39(1): 523-536.
6. Hilal $Y$, Engelhardt U. Characterization of white teaComparison to green and black tea. J. Verbrauch Lebensm. 2007; 2: 414-421.

7. Balentine DA, Wiseman SA, Frei B. Antioxidants in tea. Critical reviews in food science and nutrition. 1997; 37(8): 705-718.

8. Suganuma M, Fujiki H, Okabe S, Sueoka E, Suga K, Imai $K$. A new concept of tumor promotion by tumor necrosis factor-alpha, and cancer preventive agents (-)epigallocatechin gallate and green tea. Cancer Detect Prev. 2000; 24(1): 91-99.

9. Muramatsu K, Fukuyo M, Hara Y. Effect of green tea catechins on plasma cholesterol level in cholesterol-fed rats. J Nutr Sci Vitaminol. 1986; 32(6): 613-622.

10. Deng YJ, Xie H, Notkins AL, Lan MS. Expression, characterization, processing and immunogenicity of an insulin-dependent diabetes mellitus auto antigen, IA-2, in Sf-9 cells. Clin. Exp. Immunol. 1998; 113(3): 367-372.

11. Zhao $Y$, Li P, Ge L, Wang $Y$, Mo T, Zeng X. Effect of electrolyzed reduced water on chiral theanine and polyphenols in tea. Food Chem. 2012; 134(4): 17611766.

12. Cabrera $C$, Artacho R, Giménez R. Beneficial effects of green tea. A Review. J. Am. Coll. Nutr. 2006; 25: 79-99.

13. Kahkonen MP, Hopia Al, Vuorela HJ, Rauha JP, Pihlaja K, Kujala TS, Heinonen M. Antioxidant Activity of Plant Extracts Containing Phenolic Compounds. J. Agric. Food Chem. 1999; 47: 3954-3960.

14. Elmore J, Choe J. Breast cancer screening for women in their 40s: moving from controversy about data to helping individual women. Ann Intern Med. 2007; 146(7): 529531.

15. Mehta HB, Vargas GM, Adhikari D, Dimou F, Riall TS. Comparative effectiveness of chemotherapy versus resection of the primary tumor as the initial treatment in older patients with stage IV colorectal cancer. Colorectal Dis. J Assoc Coloproctol Great Brit Ireland. 2017; 19(6): 210-218.

16. Singh S, Kotla N, Tomar S, Maddiboyina B, Webster $T$, Sharma D, Sunnapu O. A nanomedicine-promising approach to provide an appropriate colon-targeted drug delivery system for 5-fluorouracil. Int $\mathrm{J}$ Nanomedicine. 2015; 10(1): 7175-7182.

17. Atlanta G. Cancer Facts \& Figures. American Cancer Society. 2014.

18. Mosmann T. Rapid colorimetric assay for cellular growth and survival: application to proliferation and cytotoxicity assays. J Immunol Methods. 1983; 65(1-2): 55-63.

19. Azadi Gonbad R, Afzan A, Karimi E, Sinniah UR, Swamy MK. Electron J Biotechnol. 18; (6): 433-438.

20. ISO14502-1. Determination of substances characteristic of green and black tea- content of total polyphenols in tea. Part 1. Colorimetric method using Folin-ciocalteu reagent. 2004.

21. Blois MS. Antioxidant determinations by the use of a stable free radical. Nature. 1958; 29: 1199 -1200.

22. Peres RG, Tonin FG, Tavares MF, Rodriguez-Amaya DB. Determination of catechins in green tea infusions by

Trop J Pharm Res, June 2018; 17(6): 1040 
reduced flow micellar electrokinetic chromatography. Food Chem. 2011; 127: 651-655.

23. Amarowicz R, Shahidi F, WIczkowski W. Separation of individual catechins from green tea using silica gel column chromatography and HPLC. J Food Lipids. 2005; 10: 165-177.

24. Bian Q, Liu P, Gu J, Song B. Tubeimoside-1 inhibits the growth and invasion of colorectal cancer cells through the Wnt/beta-catenin signaling pathway. Int J Clin Exp Pathol. 2015; 8(10): 12517-12524.

25. Hajiaghaalipour F, Kanthimathi MS, Sanusi J, Rajarajeswaran J. White tea (Camellia sinensis) inhibits proliferation of the colon cancer cell line, HT-29, activates caspases and protects DNA of normal cells against oxidative damage. Food Chem. 2015; 169: 401 410.

26. Zhao S, Chen N, Deng L. Determination of five polyphenols by HPLC/DAD and discrimination of apple varieties. Chromatographia. 2011; 5(6): 595-598.
27. Ochanda SO. A Review on Tea Manufacture, Tea Types and Tea Products in the Kenyan Tea Industry. J Tea Sci. 2010; 31: 38-48.

28. Kerio LC. Characterization of anthocyanins in Kenyan teas: Extraction and identification, Food Chem. 2012; 131(1): 31-38.

29. Guo Q, Zhao B, Shen S, Hou J, Hu J, Xin W. Study on the structure antioxidant activity relationship of tea catechins and their epimers. Biochimica ET Biophysica Acta (BBA) - General Subjects. 2000; 14(27): 13-23.

30. Katalinic V, Milos M, Jukic M. Screening of 70 medicinal plant extracts for antioxidant capacity and total phenols. Food Chem. 2006; 94: 550-557.

31. Bushman JL. Green tea and cancer in humans: a review of the literature. Nutr. Cancer. 1998; 31(3): 151-159.

32. Yang S, Maliakal $P$, Meng X. Inhibition of carcinogenesis by tea. Annu. Rev. Pharmacol. Toxicol. 2002; 42: 25-54. 